\title{
Canopy Size and Induced Resistance in Stylosanthes scabra Determine Anthracnose Severity at High $\mathrm{CO}_{2}$
}

\author{
I. B. Pangga, S. Chakraborty, and D. Yates
}

First and second authors: Cooperative Research Center for Tropical Plant Protection, University of Queensland, St. Lucia, Queensland 4072 Australia; second author: CSIRO Plant Industry, Queensland Bioscience Precinct, 306 Carmody Road, St. Lucia, Queensland 4067 Australia; and third author: Department of Botany, University of Queensland, St. Lucia, Queensland 4072 Australia. Accepted for publication 7 October 2003.

\begin{abstract}
Pangga, I. B., Chakraborty, S., and Yates, D. 2004. Canopy size and induced resistance in Stylosanthes scabra determine anthracnose severity at high $\mathrm{CO}_{2}$. Phytopathology 94:221-227.

This study examines the relative importance of canopy size and induced resistance to Colletotrichum gloeosporioides at 350- and 700-ppm atmospheric $\mathrm{CO}_{2}$ concentrations on susceptible Stylosanthes scabra 'Fitzroy' from two studies in a controlled environment facility (CEF) and in the field. Plants were grown at the two $\mathrm{CO}_{2}$ concentrations in a repeated experiment in the CEF and inoculated at 6,9 , or 12 weeks of age. Although the physiological maturity of plants was at a similar stage for all three ages, the number of lesions per plant increased with increasing plant age at both $\mathrm{CO}_{2}$ concentrations. At $350 \mathrm{ppm}$, the increase was associated with canopy size and increasing infection efficiency of the

pathogen, but at $700 \mathrm{ppm}$, it was associated only with canopy size, because infection efficiency did not change with increasing age. A level of resistance was induced in plants at $700 \mathrm{ppm} \mathrm{CO}_{2}$. In a second study, plants were raised for 12 to 14 weeks at the two $\mathrm{CO}_{2}$ concentrations in the $\mathrm{CEF}$ and exposed to C. gloeosporioides inoculum in replicated field plots under ambient $\mathrm{CO}_{2}$ over three successive years. Fitzroy developed a dense and enlarged canopy, with 28 to $46 \%$ more nodes, leaf area, and aboveground biomass at high $\mathrm{CO}_{2}$ than at low $\mathrm{CO}_{2}$. Up to twice as many lesions per plant were produced in the high $\mathrm{CO}_{2}$ plants, because the enlarged canopy trapped many more pathogen spores. The transient induced resistance in high $\mathrm{CO}_{2}$ plants failed to operate when exposed to pathogen inoculum under ambient $\mathrm{CO}_{2}$ in the field. These results highlight the need to consider both canopy size and host resistance in assessing the influence of elevated $\mathrm{CO}_{2}$ on plant disease.
\end{abstract}

According to measurements from the Vostok ice core in Antarctica, $\mathrm{CO}_{2}$ concentration in the atmosphere has fluctuated between 180 and 280 ppm for the past 420,000 years (28), but it has increased from 280 to $367 \mathrm{ppm}$ between 1750 and 1999, a rise of $31 \%$, as a consequence of $\mathrm{CO}_{2}$ emissions from fossil fuel burning and deforestation. By 2100, carbon cycle models project atmospheric $\mathrm{CO}_{2}$ concentrations of between 540 and $970 \mathrm{ppm}$ based on different emission scenarios (17).

There is extensive literature on the response of plants to atmospheric $\mathrm{CO}_{2}$. Increased photosynthesis and water use efficiency at high $\mathrm{CO}_{2}$ leads to higher biomass and yield $(20,21)$. Plant morphology changes due to increased number of nodes, greater internode length, stimulated leaf expansion, and reduced apical dominance $(30,33)$ and changes in rules of morphogenesis make the canopy dense and enlarged (27). If other factors are nonlimiting, a doubling of $\mathrm{CO}_{2}$ increases yield by about $30 \%$ in most crops with a $\mathrm{C}_{3}$ photosynthetic pathway (20). However, yield increases have been observed mostly in experiments in which damage from plant disease, herbivory, or weed competition has not been considered.

Among agricultural pests, pathogens have received far less attention than insects (31), and there is a critical shortage of information on the influence of elevated $\mathrm{CO}_{2}$ on plant diseases. In the few studies in which $\mathrm{CO}_{2}$ effects on disease have been considered $(8,23)$, disease severity has increased, decreased, or remained unchanged $(5,8,23,35)$ due to changes in host morphology and physiology. In barley, the rate of primary penetration of Erysiphe graminis causing powdery mildew was reduced at $700 \mathrm{ppm} \mathrm{CO}_{2}$

Corresponding author: S. Chakraborty

E-mail address: Sukumar.Chakraborty@ csiro.au

Publication no. P-2003-1229-02R

(C) 2004 The American Phytopathological Society due to higher net photosynthetic rate allowing an increased mobilization of resources into resistance such as the accumulation of silicate at penetration sites and the production of papillae (14). Host nutritional status $(34)$, UV-B $(5,23)$, and $\mathrm{O}_{3}(19,36)$ influence the expression of resistance at high $\mathrm{CO}_{2}$. Severity of E. graminis in wheat is reduced by lowered plant nitrogen but raised by increased water content (34). In addition to resistance, $\mathrm{CO}_{2}$-induced modifications to plant canopy and its microclimate and pathogen populations can potentially influence the severity, epidemiology, and management of diseases; but these have not been examined in any study.

In Australia, Stylosanthes scabra is an economically significant pasture legume that is grown in over $1 \mathrm{~m}$ ha. Anthracnose disease, caused by Colletotrichum gloeosporioides (Penz.) Penz. \& Sacc., seriously limits the utilization of this legume in tropical and subtropical Australia. In the 1970 s, 500,000 ha of pastures with susceptible $S$. humilis cultivars were devastated by anthracnose. A critical understanding of the host-pathogen interaction under elevated $\mathrm{CO}_{2}$ is of particular relevance to perennial pasture species such as Stylosanthes, because unlike annual crops, these plants cannot be quickly and easily replaced by cultivars more suited to increased $\mathrm{CO}_{2}$ concentrations. We have previously shown that elevated $\mathrm{CO}_{2}$ influences both host and pathogen, and cultivars differ in their expression of resistance to anthracnose at $700 \mathrm{ppm}$ of $\mathrm{CO}_{2}$ (6). The susceptible cv. Fitzroy develops a level of partial resistance at $700 \mathrm{ppm} \mathrm{CO}_{2}$, whereas the response of resistant cv. Seca remains largely unchanged (6). Among pathogen attributes, conidia germination, germ tube growth, and appressorial production by $C$. gloeosporioides were measured on leaf surface by sampling inoculated leaves at different times after inoculation. At $700 \mathrm{ppm} \mathrm{CO}_{2}$, fewer conidia germinated and produced appressoria than at ambient $\mathrm{CO}_{2}$ and the growth of germ tube and appressoria production was delayed by 3 to $6 \mathrm{~h}$. These contrib- 
uted to a longer incubation period and a reduced disease severity at $700 \mathrm{ppm} \mathrm{CO}_{2}$, but the latent period remained unchanged and the number of spores produced per unit lesion area increased by more than twofold from an enhanced pathogen fecundity (6). Our results are similar to findings on barley powdery mildew, where despite initial delays and reductions in host penetration, the latent period was unaffected as established colonies grew faster inside host tissue at elevated $\mathrm{CO}_{2}$ (14). We have recently shown that the enhanced host resistance in $S$. scabra at $700 \mathrm{ppm} \mathrm{CO}_{2}$ reduces the overall aggressiveness of $C$. gloeosporioides, and it does not initially increase under sequential infection cycles (4). In contrast, aggressiveness steadily increases with infection cycles at ambient $\mathrm{CO}_{2}$. Again, pathogen fecundity increases with each infection cycle at $700 \mathrm{ppm}$ but not at ambient $\mathrm{CO}_{2}$. Research in our laboratory $(4,6,27)$ points to three factors as critical to anthracnose epidemiology under elevated $\mathrm{CO}_{2}$ : a change in resistance in some cultivars; an increased amount of utilizable host tissue due to an enlarged canopy; and increased inoculum due to enhanced pathogen fecundity.

Research on other plant species has shown that some host physiological changes do not persist when plants are grown at elevated $\mathrm{CO}_{2}$ for a long period of time or over a number of generations $(10,16,24)$. For instance, the increased biosynthesis of plant metabolites such as phenolics, which are associated with resistance response in many host plants, is not sustained in some species (11). An enlarged plant canopy, on the other hand, continues to provide infection sites for the large number of pathogen propagules produced as a result of increased fecundity. Therefore, host resistance alone cannot explain disease severity at elevated $\mathrm{CO}_{2}$ and other associated changes need to be considered.

The aim of this work is to provide a comparative analysis of the role of induced host resistance and canopy size under $700 \mathrm{ppm}$ $\mathrm{CO}_{2}$ on anthracnose severity in susceptible $S$. scabra cv. Fitzroy.

\section{MATERIALS AND METHODS}

Two experiments were conducted to examine the relative importance of canopy size and host resistance at 350 and $700 \mathrm{ppm}$ $\mathrm{CO}_{2}$. Firstly, resistance and canopy size were considered using plants of three different age groups at the two $\mathrm{CO}_{2}$ concentrations; and secondly, the influence of canopy size was examined by exposing plants of different canopy sizes from the two $\mathrm{CO}_{2}$ concentrations to natural $C$. gloeosporioides inoculum in the field under ambient atmospheric $\mathrm{CO}_{2}$.

Plant age, canopy size, and $\mathrm{CO}_{2}$ concentration. The influence of plant age, canopy size, and $\mathrm{CO}_{2}$ concentration on anthracnose severity was determined from a repeated experiment in a controlled environment facility (CEF) at CSIRO Plant Industry, Brisbane, Australia. Internal replications were maintained within each run of the experiment, and the two runs were treated as independent replications in time. For controlled environments, repeats in time is an effective way to replicate an experiment (29). In each run of the experiment, 15 seedlings each of susceptible $S$. scabra 'Fitzroy' were grown at 350- or 700-ppm $\mathrm{CO}_{2}$ concentrations for 6,9 , or 12 weeks in two separate growth rooms using a staggered planting schedule. Plants of all three ages were in vegetative growth stage 12 according to the Winch system of classification of legume growth stage keys (18). Except for $\mathrm{CO}_{2}$ concentration, 65/95\% day/night relative humidity, $30 / 25^{\circ} \mathrm{C}$ day/night temperature, 12-h photoperiod, and $500 \mu \mathrm{mol} \mathrm{m} \mathrm{m}^{-2} \mathrm{~s}^{-1}$ photosynthetic photon flux density were maintained in both growth rooms. Growth rooms were switched between runs, and the room with $350 \mathrm{ppm} \mathrm{CO}_{2}$ during the first run was used for $700 \mathrm{ppm} \mathrm{CO}_{2}$ in the repeat run of the experiment. Six-week-old plants were raised in plastic cups ( 4 by $4 \mathrm{~cm}$ ), and 9- and 12-week-old plants were raised in plastic pots containing approximately $800 \mathrm{~g}$ of sandy loam soil. Plants were regularly fertilized with a nutrient solution (Thrive; Arthur Yates and Co., New South Wales, Australia).
C. gloeosporioides isolate SR24 was grown on oatmeal agar (2\% rolled oats and $2 \%$ technical agar) for 7 days under near-UV light at $25^{\circ} \mathrm{C}$. An inoculum suspension was prepared in distilled water by scraping the surface of cultures and filtering through two layers of cheesecloth. The inoculum was standardized to $5 \times$ $10^{5}$ conidia per $\mathrm{ml}$.

Twelve 'Fitzroy' plants from each age group at each $\mathrm{CO}_{2}$ concentration were inoculated by spraying until runoff with a pressurized sprayer (Wattyl Jet-Pack, Sydney, New South Wales, Australia). Of these, four plants were used to determine the number of conidia deposited on leaves $1 \mathrm{~h}$ after inoculation, and the remaining eight were placed in dew chambers inside their respective $\mathrm{CO}_{2}$ growth rooms for $48 \mathrm{~h}$ and incubated for another 10 days outside the dew chamber before disease assessment. Before inoculation, plant height and number of branches and nodes were recorded on four plants taken at random from the pool of 15 plants per $\mathrm{CO}_{2}$ concentration for each age group. Three other plants from each age group at each $\mathrm{CO}_{2}$ were sprayed with sterile distilled water as disease-free controls and leaf area and aboveground biomass were recorded from these plants.

To determine the number of conidia deposited on leaf surface, two infected leaflets per plant were sampled for the 6-week-old plants. For 9- and 12-week-old plants, the canopy was divided into two and three vertical layers, respectively, and two leaflets per layer were sampled per plant. A strip of transparent adhesive tape was pressed against the upper leaf surface to remove conidia, mounted on microscope slides, and stained with cotton blue, and conidia were counted from 10 microscopic fields per leaflet. The leaf area was measured with a leaf area meter (Li-Cor, Inc., Lincoln, NE), and the number of conidia per leaflet was estimated with the spore counts on adhesive tapes and expressed as conidia per leaf. Infection efficiency (IE) per leaf was calculated as IE = lesions/conidia $\times 100$, where lesions is the total number of lesions per leaf and conidia is the number of conidia deposited per leaf. Previous work showed that IE is higher on younger leaves than on older leaves (7). Because young leaves on growing apices of secondary and tertiary branches are widely distributed within a canopy, it was not possible to separate leaves according to their age based on the vertical layers, and data on IE for leaves were pooled and expressed on a per plant basis.

Both resistant and susceptible cultivars of $S$. scabra give a mesothetic reaction to infection, producing a mixture of different types of lesions on the same leaf (3). For simplicity, anthracnose lesions were classified as susceptible or resistant, and their number was recorded 10 days after inoculation for each infected leaf. Minute brown specks of $<0.5 \mathrm{~mm}$ in diameter were classed as resistant lesions and lesions of $>0.5 \mathrm{~mm}$ with dark brown margin and gray center as susceptible (3).

The effect of plant age and $\mathrm{CO}_{2}$ on each morphological or disease variable was examined using a summary analysis of variance with a split-plot design with $\mathrm{CO}_{2}$ as the main plot and plant age as the subplot using SAS (SAS Institute, Cary, NC). Node, lesion, and spore number were $\ln$-transformed, whereas leaf area and IE were square root-transformed to stabilize variance. Least square means were used to compare treatment means. In addition, the influence of plant age within each $\mathrm{CO}_{2}$ concentration was further explored using linear regression analysis.

Field study. 'Fitzroy' plants, raised either at 350- or 700-ppm $\mathrm{CO}_{2}$ concentration in the CEF for 12 to 14 weeks, were exposed to C. gloeosporioides inoculum in the field at the CSIRO Samford Pasture Research Station $\left(27^{\circ} 22^{\prime} \mathrm{S}, 152^{\circ} 53^{\prime} \mathrm{E}\right)$ during the summer of 1997,1998 , and 1999. To provide a source of inoculum in each year, three replicate plots, $43.6 \mathrm{~m}^{2}$ each $(6.6$ by $6.6 \mathrm{~m})$, were laid out with $25 \mathrm{~m}$ on all sides to avoid inter-plot interference. These plots were transplanted with 6-week-old 'Fitzroy' plants grown in peat cups $(4$ by $4 \mathrm{~cm}$ ) in a naturally illuminated glasshouse at ambient $\mathrm{CO}_{2}$. A spacing of $60 \mathrm{~cm}$ between and within rows was used to accommodate 100 plants per plot. Three weeks after trans- 
planting, all plants were inoculated with $5 \times 10^{5}$ conidia per $\mathrm{ml}$ (isolate SR24) suspension with a pressurized sprayer (Hozelock Ltd., Haddenham, England). Plants were inoculated in the evening to allow adequate surface wetness duration (7) for infection during the night.

Batches of disease-free Fitzroy plants were raised in plastic pots (10-cm diameter, $14 \mathrm{~cm}$ height) with one plant per pot at each of the two $\mathrm{CO}_{2}$ concentrations in the CEF for 1997 and 1999 seasons. Due to a shortage of CEF space in 1998, plants were grown in growth cabinets maintained at 350 or $700 \mathrm{ppm} \mathrm{CO}_{2}$ at the Cooperative Research Center for Tropical Plant Protection, University of Queensland or CSIRO Entomology, Long Pocket Laboratories, Brisbane. The photosynthetic photon flux density in these cabinets was lower $\left(200 \mu \mathrm{mol} \mathrm{m} \mathrm{m}^{-2} \mathrm{~s}^{-1}\right)$ than in the CEF, but temperature, relative humidity, and photoperiod settings were the same. For each batch, three plants from each $\mathrm{CO}_{2}$ concentration were destructively sampled to record leaf area per plant, number of nodes, and aboveground biomass.

Leaving the two outside rows on all four sides, 49 holes $(12-\mathrm{cm}$ diameter and $15 \mathrm{~cm}$ deep to accommodate a single potted plant), equidistant from the four nearest infected plants, were dug in between the rows in each field plot. Starting 3 weeks after inoculation of the field plants, batches of disease-free potted Fitzroy plants from the two $\mathrm{CO}_{2}$ concentrations were exposed to $C$. gloeosporioides inoculum in the field. Three plants from each $\mathrm{CO}_{2}$ concentration were placed in three randomly selected holes in each plot on five different dates each in 1997 and 1998 and on three dates in 1999. Successive batches of plants were exposed for $48 \mathrm{~h}$. After exposure, plants were transported to a glasshouse at ambient $\mathrm{CO}_{2}$ and placed inside a dew chamber for $48 \mathrm{~h}$ at $25 \pm$ $5^{\circ} \mathrm{C}$ and outside the dew chamber in the same glasshouse for another 10 days before disease and other assessments were made. The number of resistant and susceptible lesions per leaf was counted as before.

On two occasions in 1999, the number of C. gloeosporioides conidia trapped inside the canopy after $48 \mathrm{~h}$ in the field was determined from three replicate plants for each $\mathrm{CO}_{2}$ concentration using one plant from each plot. The entire plant without roots was dipped in 1 liter of sterile distilled water with 5 drops of $0.1 \%$ Tween 20 in a 2-liter plastic container and shaken in an orbital shaker for $2 \mathrm{~h}$. The resulting suspension was centrifuged for $20 \mathrm{~min}$ at 4,000 $\mathrm{rpm}$, the pellet was resuspended in $25 \mathrm{ml}$ of distilled water, and conidia were counted from aliquots by a hemacytometer.

With five dates of exposure in each of 1997 and 1998 and three dates in 1999, there were 13 dates for the 3 years, and nine plants from each $\mathrm{CO}_{2}$ concentration were exposed on each date. A preliminary analysis of variance showed no significant difference between the three plots, and for each date, all nine plants at each $\mathrm{CO}_{2}$ concentration were treated as replicates after pooling data for all plots. Dates were nested within years, and years and $\mathrm{CO}_{2}$ concentrations were considered as crossed factors in an analyses of variance. Lesion number and aboveground biomass were $\ln (x+1)$ transformed, while disease severity and leaf area were square root $(x+0.5)$ transformed to stabilize variance. Least square means were used to compare treatment means. Analyses were carried out using SAS.

\section{RESULTS}

Plant growth and morphology. There was no significant difference between the repeat runs of the CEF experiment. The plants at 6,9 , and 12 weeks of age at both $\mathrm{CO}_{2}$ concentrations were in vegetative growth stage 12 (18); thus providing three different canopy sizes among plants of a similar physiological maturity. The effect of plant age was significant $(P \leq 0.01)$ for all morphological attributes (output of analysis not shown). Mean plant height, number of branches and nodes, aboveground bio- mass, and leaf area were between 18 and $39 \%$ greater at 700 ppm than at 350-ppm $\mathrm{CO}_{2}$ concentration across the three plant ages (Fig. 1). However, the overall effect of $\mathrm{CO}_{2}$ was only significant $(P \leq 0.05)$ for the number of nodes and aboveground biomass. There was a significant $\mathrm{CO}_{2}$-plant age interaction $(P \leq 0.001)$ for height and the number of branches, but not for the other attributes. Nine- and twelve-week-old plants grew significantly taller with more branches at $700 \mathrm{ppm}$ than at $350 \mathrm{ppm} \mathrm{CO}_{2}$, and aboveground biomass was significantly greater at $700 \mathrm{ppm}$ for all age groups. In contrast, significantly greater leaf area at $700 \mathrm{ppm} \mathrm{CO}_{2}$ was only recorded in 12-week-old plants (Fig. 1). This indicates that aboveground biomass provides the most consistent measure of increased plant growth at $700 \mathrm{ppm} \mathrm{CO}_{2}$.
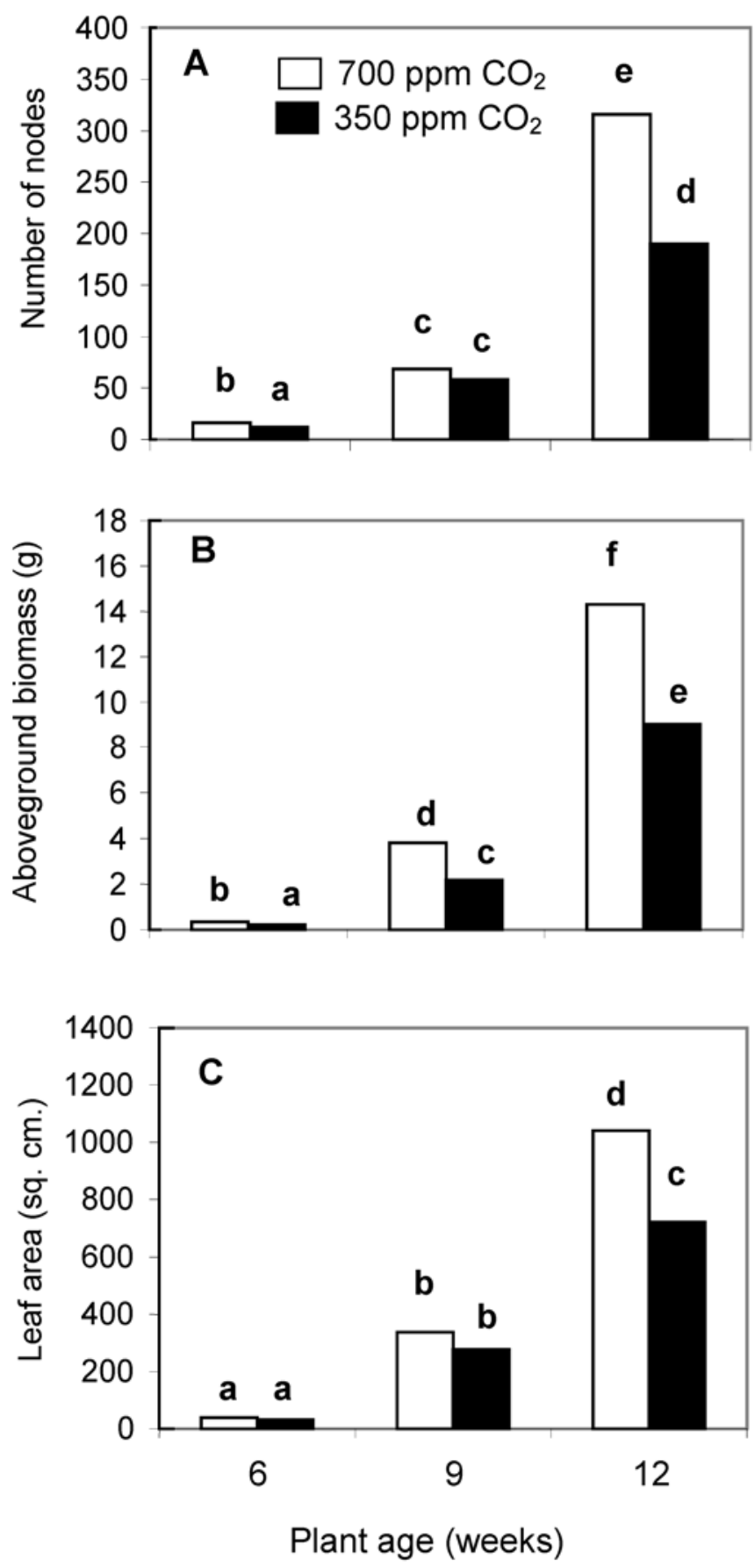

Fig. 1. Number of nodes, aboveground biomass, and leaf area of 6-, 9-, and 12-week-old disease-free Stylosanthes scabra 'Fitzroy' grown at 350 and $700 \mathrm{ppm} \mathrm{CO}_{2}$. Least square means with the same letter are not significantly different at $P \leq 0.05$. Data are means of three to four plants in each of two runs for each age group per $\mathrm{CO}_{2}$ concentration. 
Similarly, plants grown for 12 to 14 weeks at $700 \mathrm{ppm} \mathrm{CO}_{2}$ in the CEF for field exposure had up to $28 \%$ greater leaf area, $36 \%$ more nodes, and $46 \%$ more biomass than plants at $350 \mathrm{ppm} \mathrm{CO}_{2}$ (data not shown). These plants were also in vegetative growth stage 12 (18), similar to those used in the CEF experiments. Aboveground biomass, leaf area, and nodes per plant were significantly greater for plants grown at $700 \mathrm{ppm} \mathrm{CO}_{2}$ than at $350 \mathrm{ppm} \mathrm{CO}_{2}$ in each of the 3 years of the study. The lowest aboveground biomass was recorded in 1998 for plants in growth cabinets with $40 \%$ lower photosynthetic photon flux density than the CEF growth rooms used in 1997 and 1999; but plants at $700 \mathrm{ppm}$ still had significantly higher biomass, nodes, and leaf area than those at 350 ppm $\mathrm{CO}_{2}$.

Plant age, canopy size, and anthracnose. The mean number of susceptible, resistant, and total lesions per leaf averaged over the three plant ages was significantly $(P \leq 0.05)$ greater at $350 \mathrm{ppm}$ than at $700 \mathrm{ppm} \mathrm{CO}_{2}$ (data not shown), reflecting the development of a level of resistance in susceptible cv. Fitzroy at high $\mathrm{CO}_{2}$. Plant age also significantly $(P \leq 0.001)$ influenced the number of susceptible, resistant, and total lesions per leaf. Both susceptible and resistant lesions per leaf increased with plant age at $350 \mathrm{ppm} \mathrm{CO}_{2}$; at $700 \mathrm{ppm}$, these increased in 6- and 9-weekold plants but declined significantly in 12-week-old plants (Fig. 2 ). For the three age groups, the difference in lesions per leaf between the two $\mathrm{CO}_{2}$ concentrations was only significant for the 12-week-old plants but not for the 6- or 9-week-old plants. At 12 weeks of age, plants at $350 \mathrm{ppm}$ had 60 and $75 \%$ more susceptible and resistant lesions per leaf, respectively, than those at $700 \mathrm{ppm} \mathrm{CO}_{2}$. The $\mathrm{CO}_{2}$-plant age interaction was not significant for resistant or susceptible lesions per leaf (data not shown).

Increased resistance at $700 \mathrm{ppm} \mathrm{CO}_{2}$ is clearly evident from the significant $(P \leq 0.001)$ reduction in the mean IE. However, the difference in IE between 350 and $700 \mathrm{ppm} \mathrm{CO}_{2}$ was only significant for 12-week-old plants (Table 1). Although the overall effect of plant age on IE was significant $(P \leq 0.05)$, this was influenced by the $\mathrm{CO}_{2}$ concentration. Unlike at $350 \mathrm{ppm}$, where IE was significantly $(P \leq 0.05)$ higher at 9 and 12 weeks than at 6 weeks, at $700 \mathrm{ppm} \mathrm{CO}_{2}$ there was no significant difference in IE between plants of different ages (Table 1). This suggests that the enhancement in host resistance at $700 \mathrm{ppm} \mathrm{CO}_{2}$ operates irrespective of plant age.
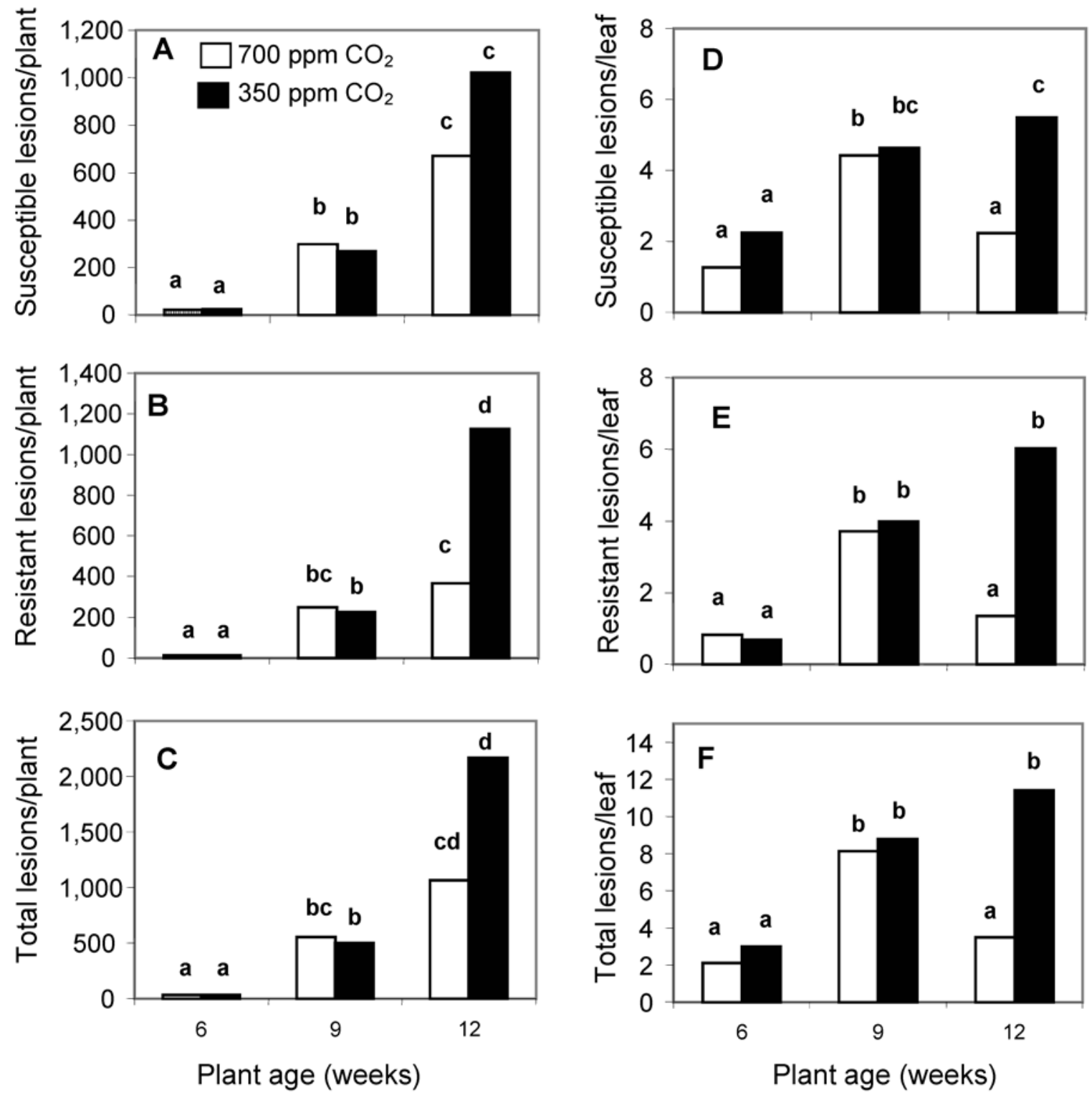

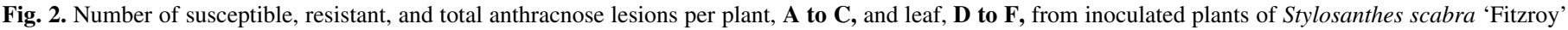

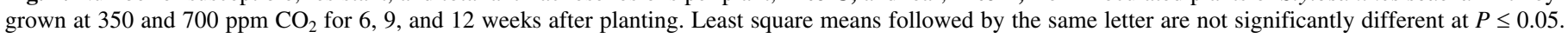
Data are means of eight plants in each of two runs for each age group per $\mathrm{CO}_{2}$ concentration. 
At the plant level, both $\mathrm{CO}_{2}(P \leq 0.05)$ and plant age $(P \leq$ 0.001 ) had a significant effect on total lesions and the $\mathrm{CO}_{2}$-plant age interaction was significant $(P \leq 0.05)$ for both types of lesions (data not shown). Resistant and susceptible lesions per plant, averaged over all ages, were consistently higher at $350 \mathrm{ppm}$ than at $700 \mathrm{ppm} \mathrm{CO}_{2}$, but the difference was only significant for total lesions (data not shown). The large difference among the 12-weekold plants mainly contributed to the difference between the two $\mathrm{CO}_{2}$ concentrations (Fig. 2). In general, the number of susceptible, resistant, and total lesions per plant increased with increasing plant age and canopy size at both $\mathrm{CO}_{2}$ concentrations (Fig. 2). This is despite a significant $(P \leq 0.05)$ reduction in IE at $700 \mathrm{ppm}$ $\mathrm{CO}_{2}$ among the 12-week-old plants (Table 1).

Linear regression analysis of the influence of plant age on resistant, susceptible, and total lesions per leaf and plant confirmed the trend observed with the analysis of variance. At $350 \mathrm{ppm} \mathrm{CO}_{2}$, resistant, susceptible, and total lesions increased with plant age (Table 2). At $700 \mathrm{ppm} \mathrm{CO}_{2}$, plant age did not significantly influence resistant, susceptible, or total lesions per leaf due to enhanced host resistance; at the plant level, on the other hand, all types of lesions increased with plant age, because larger plants offered many more infection sites.

Anthracnose development in the field. The induced resistance in Fitzroy grown at $700 \mathrm{ppm} \mathrm{CO}_{2}$ disappeared almost completely when plants were exposed to inoculum in the field at ambient $\mathrm{CO}_{2}$. There was no significant difference in lesion number per leaf between the two $\mathrm{CO}_{2}$ concentrations. However, lesions per leaf were almost always lower in plants from $700 \mathrm{ppm}$ than those from $350 \mathrm{ppm} \mathrm{CO}_{2}$ (Table 3), suggesting that the high $\mathrm{CO}_{2}$ plants may have retained a low level of resistance. The trend was similar for both the number of susceptible and resistant lesions per leaf, and data are presented for total lesions per leaf (Table 3).

TABLE 1. Infection efficiency of Colletotrichum gloeosporioides on 6-, 9-, and 12-week-old Stylosanthes scabra 'Fitzroy' grown at 350 and 700 ppm $\mathrm{CO}_{2}$ in a controlled environment facility

\begin{tabular}{lcc}
\hline \multirow{2}{*}{$\begin{array}{l}\text { Plant age } \\
\text { (weeks after planting) }\end{array}$} & \multicolumn{2}{c}{ Infection efficiency $^{\mathrm{z}}$} \\
\cline { 2 - 3 } 6 & $350 \mathrm{ppm} \mathrm{CO} \mathrm{CO}_{2}$ & $700 \mathrm{ppm} \mathrm{CO}_{2}$ \\
\hline 6 & $0.87 \mathrm{Aa}$ & $0.85 \mathrm{Aa}$ \\
12 & $1.19 \mathrm{Ba}$ & $1.10 \mathrm{Aa}$ \\
Mean & $1.34 \mathrm{Ba}$ & $1.04 \mathrm{Ab}$ \\
\hline
\end{tabular}

z Data, [square root $(x+0.5)$ ] transformed, are means of four plants in each of two runs for each age group per $\mathrm{CO}_{2}$ concentration. In a row, least square means followed by the same lowercase letter are not significantly different $(P \leq 0.05)$. In a column, least square means followed by the same uppercase letter are not significantly different $(P \leq 0.05)$.
When data for the entire plant were considered, the effect of canopy size was clearly evident from the significantly increased mean number of lesions per plant $(P<0.001)$ for the 700 -ppm $\mathrm{CO}_{2}$ plants. Plants with enlarged canopy from $700 \mathrm{ppm} \mathrm{CO}_{2}$ had many more lesions compared with those from $350 \mathrm{ppm}$ in each year, and the difference was significant for 2 of the 3 years (Table 3 ). The number of susceptible and resistant lesions per plant also followed a similar trend (data not shown).

Under field conditions, in which inoculum from the infected plants was allowed to spread naturally to the exposed plants in 1999, the enlarged canopy of two batches of plants grown at 700 ppm trapped an average of $20 \%$ more conidia than plants grown at $350 \mathrm{ppm} \mathrm{CO}_{2}$. Between $1.2 \times 10^{4}$ and $3.2 \times 10^{4}$ conidia per plant were recovered from the 700-ppm plants and between $5.4 \times 10^{3}$ and $3 \times 10^{4}$ conidia per plant were recovered from the 350-ppm $\mathrm{CO}_{2}$ plants. The consistent trend clearly shows the ability of the enlarged and dense canopy to trap an increased number of pathogen conidia. However, the difference between the two $\mathrm{CO}_{2}$ concentrations was not significant due to large variations in the number of conidia trapped.

\section{DISCUSSION}

We have examined the relative importance of canopy size and host resistance in susceptible $S$. scabra 'Fitzroy' under 350- and 700-ppm $\mathrm{CO}_{2}$ concentrations to show that canopy size, brought about by plants of different age with the same physiological maturity, modified the effect of induced partial resistance at 700 ppm $\mathrm{CO}_{2}$ and the number of anthracnose lesions per plant increased with increasing canopy size. The enhanced resistance of Fitzroy is clearly evident from an overall reduction in IE of $C$. gloeosporioides at high $\mathrm{CO}_{2}$, which causes a reduction in the number of lesions per leaf. However, a dense and enlarged

TABLE 3. Anthracnose lesions per leaf and plant on 13 different dates in batches of Stylosanthes scabra 'Fitzroy' grown under 350 and 700 ppm CO in a controlled environment and exposed to Colletotrichum gloeosporioides inoculum in the field during a 3-year period

\begin{tabular}{lcccc}
\hline & \multirow{2}{*}{$\begin{array}{c}\mathrm{CO}_{2} \text { concen- } \\
\text { Attribute }\end{array}$} & \multicolumn{3}{c}{ Year $^{\mathrm{z}}$} \\
\cline { 3 - 5 } & tration $(\mathrm{ppm})$ & 1997 & 1998 & 1999 \\
\hline Lesions per leaf & 350 & $0.41 \mathrm{a}$ & $0.25 \mathrm{a}$ & $0.14 \mathrm{a}$ \\
& 700 & $0.46 \mathrm{a}$ & $0.17 \mathrm{a}$ & $0.11 \mathrm{a}$ \\
Lesions per plant & 350 & $3.07 \mathrm{a}$ & $2.64 \mathrm{a}$ & $2.47 \mathrm{a}$ \\
& 700 & $4.01 \mathrm{~b}$ & $3.18 \mathrm{~b}$ & $2.61 \mathrm{a}$ \\
\hline
\end{tabular}

${ }^{y}$ Data, $\ln (x+1)$ transformed, are means of nine plants in each of the 13 dates per $\mathrm{CO}_{2}$ concentration.

${ }^{\mathrm{z}}$ For an attribute, least square means followed by the same letter in a column are not significantly different at $P \leq 0.05$.

TABLE 2. Linear regression analysis of the influence of plant age on anthracnose lesions in Stylosanthes scabra 'Fitzroy' plants grown under 350- and 700-ppm $\mathrm{CO}_{2}$ concentrations in a controlled environment

\begin{tabular}{|c|c|c|c|c|c|}
\hline \multirow[b]{2}{*}{ Attribute } & \multirow[b]{2}{*}{$\mathrm{CO}_{2}$ concentration $(\mathrm{ppm})$} & \multirow[b]{2}{*}{ Lesions } & \multicolumn{2}{|c|}{ Parameter estimatey } & \multirow[b]{2}{*}{$P>|F|^{\mathrm{z}}$} \\
\hline & & & Intercept & Age & \\
\hline Lesions per leaf & $\begin{array}{l}350 \\
350 \\
350 \\
700 \\
700 \\
700\end{array}$ & $\begin{array}{l}\text { Resistant } \\
\text { Susceptible } \\
\text { Total } \\
\text { Resistant } \\
\text { Susceptible } \\
\text { Total }\end{array}$ & $\begin{array}{r}-0.48( \pm 0.46)^{\mathrm{ns}} \\
0.43( \pm 0.39)^{\mathrm{ns}} \\
0.35( \pm 0.46)^{\mathrm{ns}} \\
0.63( \pm 0.64)^{\mathrm{ns}} \\
0.71( \pm 0.46)^{\mathrm{ns}} \\
1.06( \pm 0.64)^{\mathrm{ns}}\end{array}$ & $\begin{array}{l}0.21( \pm 0.05) \\
0.13( \pm 0.04) \\
0.19( \pm 0.05) \\
0.04( \pm 0.06) \\
0.05( \pm 0.05) \\
0.06( \pm 0.07)\end{array}$ & $\begin{array}{l}<0.001 \\
<0.01 \\
<0.003 \\
<0.56 \\
<0.27 \\
<0.39\end{array}$ \\
\hline Lesions per plant & $\begin{array}{l}350 \\
350 \\
350 \\
700 \\
700 \\
700\end{array}$ & $\begin{array}{l}\text { Resistant } \\
\text { Susceptible } \\
\text { Total } \\
\text { Resistant } \\
\text { Susceptible } \\
\text { Total }\end{array}$ & $\begin{array}{r}-1.81( \pm 0.76) \\
-0.37( \pm 0.62)^{\mathrm{ns}} \\
-0.33( \pm 0.67)^{\mathrm{ns}} \\
-0.27( \pm 1.08)^{\mathrm{ns}} \\
-0.09( \pm 0.68)^{\mathrm{ns}} \\
0.47( \pm 0.84)^{\mathrm{ns}}\end{array}$ & $\begin{array}{l}0.75( \pm 0.08) \\
0.62( \pm 0.06) \\
0.68( \pm 0.07) \\
0.55( \pm 0.11) \\
0.57( \pm 0.07) \\
0.57( \pm 0.09)\end{array}$ & $\begin{array}{l}<0.0001 \\
<0.0001 \\
<0.0001 \\
<0.0008 \\
<0.0001 \\
<0.0001\end{array}$ \\
\hline
\end{tabular}

y Values in parentheses are the standard error of the estimate. ns represents a nonsignificant intercept.

${ }^{z} P>F$ for plant age parameter estimate. 
canopy at high $\mathrm{CO}_{2}$, with 28 to $46 \%$ greater number of nodes, leaf area, and aboveground biomass, contains more infection sites to increase the total number of lesions per plant. The number of lesions per plant increases with increasing plant age at both $\mathrm{CO}_{2}$ concentrations; at $350 \mathrm{ppm}$, the increase is associated with canopy size and increasing IE, but at $700 \mathrm{ppm}$, it is associated only with canopy size, because IE does not change with increasing age. We have found that the induction of partial resistance in Fitzroy is transient and it does not persist if plants are removed from high $\mathrm{CO}_{2}$ and exposed to C. gloeosporioides inoculum in the field under ambient atmospheric $\mathrm{CO}_{2}$. Under field conditions, up to twice as many lesions per plant were produced in the high $\mathrm{CO}_{2}$ plants, because the enlarged canopy trapped and provided infection sites to many more pathogen spores.

Previous research $(1,12-15,20,21)$ including our own $(4,6,27)$ on this and other plant species have demonstrated changes in plant physiology and morphology at high $\mathrm{CO}_{2}$. In the current study, increased height, leaf area, aboveground biomass, and number of branches, nodes, and leaves at $700 \mathrm{ppm} \mathrm{CO}_{2}$ made the canopy large and dense in plants of all three ages in the CEF. Recent research shows that morphological changes associated with the production of a dense canopy at high $\mathrm{CO}_{2}$ are underpinned by changes in plant morphogenesis (27).

Previously, we have shown that IE of C. gloeosporioides is influenced by the level of resistance in host genotypes and by leaf age (7). IE is greater on younger, more susceptible leaves than on older leaves $(3,7)$. Using IE as an indicator of resistance, the present work clearly shows that at $350 \mathrm{ppm}$ overall susceptibility of the canopy increases with increasing age because more young leaves are produced on secondary and tertiary branches of the more advanced plants. At $700 \mathrm{ppm} \mathrm{CO}_{2}$, IE did not increase with increasing plant age despite the presence of many more young leaves in the enlarged canopy. This points to reduced pathogen efficiency or an induced partial resistance to anthracnose in Fitzroy at $700 \mathrm{ppm} \mathrm{CO}_{2}$. Similarly, the number of resistant, susceptible, and total lesions per leaf increased with increasing plant age at $350 \mathrm{ppm}$, but not at $700 \mathrm{ppm} \mathrm{CO}_{2}$. However, there was no significant difference between the two $\mathrm{CO}_{2}$ concentrations when data for the total number of resistant or susceptible lesions on the entire plant are considered. Although IE did not increase with age at $700 \mathrm{ppm} \mathrm{CO}_{2}$, lesions per plant increased with increasing age at both $\mathrm{CO}_{2}$ concentrations to clearly demonstrate the influence of canopy size.

Induced disease resistance under elevated $\mathrm{CO}_{2}$ due to modified host physiology has been reported in several studies $(8,12-14,23)$. Some of the changes in plant physiology, anatomy, and morphology that have been implicated in increased resistance or can potentially enhance host resistance at elevated $\mathrm{CO}_{2}$ include increased net photosynthesis allowing mobilization of resources into host resistance (14); reduced stomatal density and conductance $(1,12,23)$; greater accumulation of carbohydrates in leaves; more waxes, extra layers of epidermal cells, and increased fiber content (26); greater number of mesophyll cells (2); and increased biosynthesis of phenolics (11), among others. C. gloeosporioides predominantly penetrates Stylosanthes leaf tissue through the stomatal complex (25) and a reduced stomatal density and conductance may be involved in the augmented host resistance at $700 \mathrm{ppm} \mathrm{CO}_{2}$. However, the loss of resistance in plants following their removal from high $\mathrm{CO}_{2}$ indicates that structural changes in plant morphology may not be a major contributor to the enhanced host resistance. There is supportive evidence from barley mildew, in which removing the epicuticular layer from the leaf surface had no effect on the development of E. graminis conidia at 350 or $700 \mathrm{ppm} \mathrm{CO}_{2}$, indicating that structural changes such as increased epicuticular waxes are not responsible for the enhanced resistance (14). Increased resistance in barley to E. graminis is associated with increased net photosynthesis $(13,14)$, but this increase at elevated $\mathrm{CO}_{2}$ is transient (9). This is congruent with the rapid loss of enhanced resistance in Fitzroy following its removal from a high $\mathrm{CO}_{2}$ concentration. In contrast, a range of physiological, morphological, and structural changes is associated with the development of an enlarged canopy at high $\mathrm{CO}_{2}(1,15,20,21)$ and their effect persists well after the plant is removed from high $\mathrm{CO}_{2}$. The differential effects of elevated $\mathrm{CO}_{2}$ are evident in our field study where the enlarged canopy size persisted to increase the overall number of lesions but the induced host resistance failed to persist once the plants were removed from $700 \mathrm{ppm} \mathrm{CO}_{2}$.

In addition to host resistance, germination, growth, and development of many pathogens are affected at high $\mathrm{CO}_{2}$ (23), contributing to a reduced IE and the development of infection by $E$. graminis spores is arrested at the appressorial stage (14). Previously we have demonstrated reduced germination, germ tube growth, and appressorial production by $C$. gloeosporioides conidia at $700 \mathrm{ppm}$ of $\mathrm{CO}_{2}$ (6). On leaves of susceptible 'Fitzroy', spore germination was reduced from 53 to $9 \%$ at $700 \mathrm{ppm}$ as the cultivar developed enhanced resistance, whereas germination was only slightly reduced from 11 to $10 \%$ on a partially resistant cultivar. This clearly shows that the level of host resistance pre-

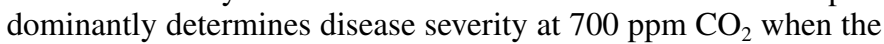
same pathogen isolate infects cultivars with different resistance levels and the $\mathrm{CO}_{2}$-induced modifications to pathogenesis are only partly responsible for the reduced severity. Although a reduced germination and delayed germ tube growth and appressorial production at $700 \mathrm{ppm} \mathrm{CO}_{2}$ extends the incubation period from 4.16 to 4.49 days and from 4.41 to 5.30 days in the susceptible and resistant cultivars, respectively, the latent period of 6.5 to 7.2 days does not change for either cultivar (6). This is similar to barley mildew where the effects of enhanced resistance at $700 \mathrm{ppm} \mathrm{CO}_{2}$ are most pronounced during prepenetration stages $(13,14)$; once inside the host tissue, the pathogen rapidly colonizes the host tissue and there is no difference in latent period.

Increased pathogen fecundity at elevated $\mathrm{CO}_{2}$ has been demonstrated in several fungi $(8,14)$ including $C$. gloeosporioides infecting Fitzroy and other $S$. scabra cultivars $(4,6)$. The increased fecundity extends to airborne fungal propagules with concentrations increasing fourfold when Populus tremuloides saplings are grown under twice ambient $\mathrm{CO}_{2}$ and to soil fungi on decomposing leaf litter, which produce fivefold more spores (22). For the polycyclic $C$. gloeosporioides, a combination of increased fecundity and enlarged canopy can potentially accelerate pathogen evolution. In addition, the modified canopy microclimate $(23,24)$ provides more favorable conditions for anthracnose development (27). There is evidence that highly aggressive $C$. gloeosporioides strains evolve at both 350 and $700 \mathrm{ppm} \mathrm{CO}_{2}$ under polycyclic infections despite the pathogen needing additional cycles to overcome the induced host resistance at high $\mathrm{CO}_{2}$ (4). However, the host population itself would evolve in response to elevated $\mathrm{CO}_{2}$ and it is uncertain whether physiological and other changes associated with elevated $\mathrm{CO}_{2}$ may persist through generations (11) to offer stable enhancements to host resistance. Long-term studies of polycyclic epidemics in free-air $\mathrm{CO}_{2}$ enrichment facility (32) are necessary for comprehensive analysis of fecundity, canopy microclimate, and host resistance.

\section{ACKNOWLEDGMENTS}

This work is a part of I. B. Pangga's Ph.D. research at the University of Queensland, funded by a scholarship from the Australian Agency for International Development (AusAid). CSIRO and the Cooperative Research Centre for Tropical Plant Protection provided infrastructure and operational support. We thank J. Tetley and L. Hart for technical assistance.

\section{LITERATURE CITED}

1. Allen, L. H., Jr. 1990. Plant responses to rising $\mathrm{CO}_{2}$ and potential interactions with air pollutants. J. Environ. Qual. 19:15-34. 
2. Bowes, G. 1993. Facing the inevitable: Plants and increasing atmospheric $\mathrm{CO}_{2}$. Annu. Rev. Plant Physiol. Plant Mol. Biol. 44:309-332.

3. Chakraborty, S., Cameron, D. F., Irwin, J. A. G., and Edye, L. E. 1988. Quantitatively expressed resistance to anthracnose (Colletotrichum gloeosporioides) in Stylosanthes scabra. Plant Pathol. 3:529-537.

4. Chakraborty, S., and Datta, S. 2003. How will plant pathogens adapt to host resistance at elevated $\mathrm{CO}_{2}$ under a changing climate? New Phytol. 159:733-742.

5. Chakraborty, S., Murray, G. M., Magarey, P. M., Yonow, T., O’Brien, R. G., Croft, B. J., Barbetti, M. J., Sivasithamparam, K., Old, K. M., Dudzinski, M. J., Sutherst, R. W., Penrose, L. J., Archer, C., and Emmett, R. W. 1998. Potential impact of climate change on plant diseases of economic significance to Australia. Aust. Plant Pathol. 27:15-35.

6. Chakraborty, S., Pangga, I. B., Lupton, J., Hart, L., Room, P. M., and Yates, D. 2000. Production and dispersal of Colletotrichum gloeosporioides spores on Stylosanthes scabra under elevated $\mathrm{CO}_{2}$. Environ. Pollut. 108:381-387.

7. Chakraborty, S., Ratcliff, D., and McKay, F. J. 1990. Anthracnose of Stylosanthes scabra: Effect of leaf surface wetness on disease severity. Plant Dis. 74:379-384.

8. Coakley, S. M., Scherm, H., and Chakraborty, S. 1999. Climate change and plant disease management. Annu. Rev. Phytopathol. 37:399-426.

9. Farrar, J. F., and Gunn, S. 1996. Effects of temperature and atmospheric carbon dioxide on source-sink relations in the context of climate change. Pages 389-406 in: Photoassimilate Distribution in Plants and Crop Source-Sink Relationships. E. Zamski and A. A. Schaffer, eds. Marcel Dekker, New York.

10. Fetcher, N., Jaeger, C. H., Strain, B. R., and Sionit, N. 1988. Long-term elevation of atmospheric $\mathrm{CO}_{2}$ concentration and the carbon exchange rates of saplings of Pinus taeda L. and Liquidambar styraciflua L. Tree Physiol. 4:255-262.

11. Hartley, S. E., Jones, C. J., Couper, G. C., and Jones, T. H. 2000. Biosynthesis of plant phenolic compounds in elevated atmospheric $\mathrm{CO}_{2}$. Glob. Change Biol. 6:497-506.

12. Hibberd, J. M., Richardson, P., Whitbread, R., and Farrar, J. F. 1996. Effects of leaf age, basal meristem and infection with powdery mildew on photosynthesis in barley grown in $700 \mu \mathrm{mol} \mathrm{mol}{ }^{-1} \mathrm{CO}_{2}$. New Phytol. 134:317-325

13. Hibberd, J. M., Whitbread, R., and Farrar, J. F. 1996. Effect of $700 \mu \mathrm{mol}$ $\mathrm{mol}^{-1} \mathrm{CO}_{2}$ and infection with powdery mildew on the growth and carbon partitioning of barley. New Phytol. 134:309-315.

14. Hibberd, J. M., Whitbread, R., and Farrar, J. F. 1996. Effect of elevated concentrations of $\mathrm{CO}_{2}$ in infection of barley by Erysiphe graminis. Physiol. Mol. Plant Pathol. 48:37-53.

15. Idso, S. B. 1989. $\mathrm{CO}_{2}$ and Global Change: Earth in Transition. IBR Press, Tempe, AZ.

16. Idso, S. B., and Idso, K. E. 2001. Effects of atmospheric $\mathrm{CO}_{2}$ enrichment on plant constituents related to animal and human health. Environ. Exp. Bot. 45:179-199.

17. Intergovernmental Panel on Climate Change. 2001. Technical summary. Pages 21-83 in: Climate Change 2001: The Scientific Basis. J. T. Houghton, Y. Ding, D. J. Griggs, M. Noguer, P. J. van den Linden, X. Dai, K. Maskell, and C. A. Johnson, eds. Cambridge University Press, Cambridge.

18. James, C. 1971. A manual of assessment keys for plant diseases. Can. Dep. Agric. Publ. No. 1458.

19. Karnosky, D. F., Percy, K. E., Xiang, B., Callan, B., Noormets, A., Mankovska, B., Hopkin, A., Sober, J., Jones, W., Dickson, R. E., and Isebrands, J. G. 2002. Interacting elevated $\mathrm{CO}_{2}$ and trophospheric $\mathrm{O}_{3}$ pre- disposes aspen (Populus tremuloides Michx.) to infection by rust (Melampsora medusae f. sp. tremuloidae). Glob. Change Biol. 8:329-338.

20. Kimball, B. A. 1983. $\mathrm{CO}_{2}$ and agricultural yield: An assemblage and analysis of 430 observations. Agron. J. 75:779-788.

21. Kimball, B. A., Pinter, P. J., Jr., Wall, G. W., Garcia, R. L., LaMorte, R. L., Jak, P. M. C., Arnoud Frumau, K. F., and Vugts, H. F. 1997. Comparisons of responses of vegetation to elevated carbon dioxide in free-air and open-top chamber facilities. Pages 131-140 in: Advances in Carbon Dioxide Research. L. H. Allen Jr., M. B. Kirkham, D. M. Olszyk, and C. E. Whitham, eds. American Society of Agronomy, Madison.

22. Klironomos, J. N., Rillig, M. C., Allen, M. A., Zak, D. R., Pregitzer, K. S., and Kubiske, M. E. 1997. Increased levels of airborne fungal spores in response to Populus tremuloides grown under elevated atmospheric $\mathrm{CO}_{2}$. Can. J. Bot. 75:160-163.

23. Manning, W. J., and Tiedemann, A. V. 1995. Climate change: Potential effects of increased atmospheric carbon dioxide $\left(\mathrm{CO}_{2}\right)$, ozone $\left(\mathrm{O}_{3}\right)$, and ultraviolet-B (UV-B), radiation on plant diseases. Environ. Pollut. 88:219245.

24. Mouseau, M., and Saugier, B. 1992. The direct effect of increased $\mathrm{CO}_{2}$ on gas exchange and growth of forest tree species. J. Exp. Bot. 43:11211130.

25. Ogle, H. J., Gowanlock, D. H., and Irwin, J. A. G. 1990. Infection of Stylosanthes guianensis and S. scabra by Colletotrichum gloeosporioides. Phytopathology 80:837-842.

26. Owensby, C. E. 1994. Climate change and grasslands: Ecosystem-level responses to elevated carbon dioxide. Proc. XVII Intl. Grassl. Congr. 1119-1124.

27. Pangga, I. B. 2002. Effects of elevated $\mathrm{CO}_{2}$ on plant architecture of Stylosanthes scabra and epidemiology of anthracnose disease. Ph.D. thesis. Department of Botany, University of Queensland.

28. Petit, J. R., Jouze, J., Raynaud, D., Barkov, N. I., Barnola, J. M., Basile, I., Bender, M., Chapellaz, J., Davis, M., Delaygue, G., Delmotte, M., Kotlyakov, V. M., Legrand, M., Lipenkov, V. Y., Lorius, C., Peplin, L., Ritz, C., Saltzman, E., and Stievenard, M. 1999. Climate and atmospheric history of the past 420,000 years from the Vostok Ice Core, Antarctica. Nature 399:429-436.

29. Potvin, C. 1993. ANOVA: Experiments in controlled environments. Pages 46-68 in: Design and Analysis of Ecological Experiments. S. M. Scheiner and J. Gurevitch, eds. Chapman and Hall, New York.

30. Pritchard, S., Rogers, H. H., Prior, S. A., and Peterson, C. M. 1999. Elevated $\mathrm{CO}_{2}$ and plant structure: A review. Glob. Change Biol. 5:807837.

31. Rosenzweig, C., and Hillel, D. 1998. Climate Change and the Global Harvest: Potential Impacts of the Greenhouse Effect on Agriculture. Oxford University Press, New York.

32. Senft, D. 1996. FACE-ing the future. Agric. Res. 43:4-6.

33. Taylor, G., Ranasinghe, S., Bosac, C., Gardner, S. D. L., and Ferris, R. 1994. Elevated $\mathrm{CO}_{2}$ and plant growth: Cellular mechanisms and responses of whole plants. J. Exp. Bot. 45:1761-1774.

34. Thompson, G. B., Brown, J. K. M., and Woodward, F. L. 1993. The effects of host carbon dioxide, nitrogen and water supply on the infection of wheat by powdery mildew and aphids. Plant Cell Environ. 16:687694.

35. Thompson, G. B., and Drake, B. G. 1994. Insects and fungi on a $C_{3}$ sedge and $\mathrm{a}_{4}$ grass exposed to elevated $\mathrm{CO}_{2}$ concentrations in open-top chambers in the field. Plant Cell Environ. 17:1161-1167.

36. Tiedemann, A. V., and Firsching, K. H. 2000. Interactive effects of elevated ozone and carbon dioxide on growth and yield of leaf rustinfected versus non-infected wheat. Environ. Pollut. 108:357-363. 